This PDF is a selection from an out-of-print volume from the National Bureau of Economic Research

Volume Title: Money in Historical Perspective

Volume Author/Editor: Anna J. Schwartz

Volume Publisher: University of Chicago Press

Volume ISBN: 0-226-74228-8

Volume URL: http://www.nber.org/books/schw87-1

Publication Date: 1987

Chapter Title: Reflections on the Gold Commission Report

Chapter Author: Anna J. Schwartz

Chapter URL: http://www.nber.org/chapters/c7509

Chapter pages in book: (p. 317 - 332) 


\section{3 \\ Reflections on the Gold Commission Report}

\subsection{Background of the Commission}

\subsubsection{Political Aspects}

The Gold Commission was established in accordance with a provision in an Act of Congress of October 7, 1980 (P.L. 96-389), of which the main matter was enlarging the quota assigned to the United States in the International Monetary Fund. The provision, introduced as an amendment to the Senate bill by Senator Jesse Helms (Republican, North Carolina), was accepted by the leadership to obtain his acquiescence to consideration by the Senate of the IMF quota enlargement. A similar arrangement was made in the House, where the amendment to the House bill was introduced by Congressman Ron Paul (Republican, Texas).

The provision directed the secretary of the Treasury to establish and chair a commission consisting of:

1. Three members of the Board of Governors of the Federal Reserve System and two members of the Council of Economic Advisers to be designated by him

2. One majority and one minority member of the Joint Economic Committee, the Committee on Banking, Housing, and Urban Affairs of the Senate, and the Committee on Banking, Finance, and Urban Affairs of the House of Representatives, to be designated by the Speaker of the House of Representatives and the President of the Senate, respectively

3. Four distinguished private citizens with business, finance, or academic backgrounds, to be designated by the secretary of the Treasury. 
The Commission was to "conduct a study to assess and make recommendations with regard to the policy of the U.S. Government concerning the role of gold in domestic and international monetary systems" and to report its findings and recommendations to the Congress no later than one year after enactment. No special budget for the Commission was provided but sums from the international operations budget of the Treasury Department were to be available to the Commission to carry out its functions.

An arrangement was reportedly made with the Carter Administration by which it would not proceed with the appointment of members of the Commission pending the November election results. If the Democrats lost, it would be left to the incoming administration to implement the provision. The new administration was slow in doing so. The names of the appointed members were not announced until June 22, 1981. The Commission's first meeting was on July $16 .{ }^{1}$

The law specified that the Commission have fifteen members plus a chairman. However, Henry Reuss, the chairman of the Joint Economic Committee, designated Chalmers Wylie, a close ally of his though a Republican, to represent the House side. Senator Jepsen, the vicechairman and a Republican, designated himself to represent the Senate side. It was obviously contrary to the law to have two Republicans as the Joint Economic Committee members. Rather than withdraw Wylie's designation, Reuss named himself as the Democratic representative of the JEC from the House side. The Commission thus ended up having three, rather than two members, as prescribed by the law, representing the JEC, and with a total of sixteen members rather than fifteen members plus the chairman.

Establishment of the Gold Commission was the third piece of legislation affecting gold in which Senator Helms was a prime mover. On his initiative, the right to include gold clauses in private contracts entered into on or after October 28, 1977, was enacted (P.L. 95-147). The program of Treasury medallion sales, in accordance with the American Arts Gold Medallion Act of November 10, 1978, was a second legislative initiative of the senator (P.L. 95-630). He was unsuccessful in subsequent efforts in 1980 to suspend Treasury gold sales and to provide for restitution of IMF gold.

\subsubsection{Economic Views of the Commission's Sponsors}

The amendment to the IMF bill was introduced and approved in the Senate on June 16, 1980, and in the House on September 18, 1980. The year-to-year change in the consumer price index in 1980 was at a postwar peak-13.5 percent. This factor clearly motivated the sponsors of the amendment, though the Senate and House protagonists expressed rather different views of the path to follow to eliminate inflation. Here 
we need to limit our purview to the statements made by the sponsors of the amendment on introducing it. We can also examine differences between the two pro-gold leaders that were made clear in hearings before the Subcommittee on Mines and Mining of the Committee of Interior and Insular Affairs of the House on Feasibility of a Return to the Gold Standard. ${ }^{2}$ The hearings were held on October 2, 1980, a few days before passage of the law enlarging the IMF quota and the provision to create the Gold Commission.

One difference between the sponsors of the amendment was revealed in their statements on introducing the amendment. In the Senate, referring to the suspension of convertibility into gold in 1971, Helms observed: "It is no coincidence that inflation of the dollar which precipitated the final break with gold, accelerated after the last vestige of gold's discipline was removed." He went on to criticize the role of the United States and the IMF in contributing to monetary instability of other nations, and to contrast the views of Keynesians and monetarists, who share skepticism about "a strong role of gold in the monetary system," with the views of classical economists who "criticize current monetary disorder and see the only proper response as reforms which take into account the changing demand for currencies, and the stability of the value of the unit of exchange." He closed with the statement, "I would expect that the commission would report to the Congress that there is little unanimity among the experts. I would expect, however, that the Keynesian view; the monetarist view; and the neoclassical view will be examined fully; the implications of each will be analyzed and recommendations will be made on the basis of the best judgment of the commission members." ${ }^{3}$ Senator Helms referred to Arthur Laffer as one of the leaders of the neoclassical view. Congressman Paul, on the other hand, in his House Statement on the amendment expressed the hope that the commission would take into "consideration the viewpoint of the neoclassical economists better known as Austrian school economists. I would suggest their view be investigated and expressed in this commission report as well."'4

This difference in the identification of the leadership of the neoclassical school of economics turns out to be significant for understanding the outcome of the Gold Commission performance.

At the hearings before the Subcommittee on Mines and Mining (held under the auspices of this subcommittee, as Congressman Paul noted, since "the House Banking Committee has been extremely reluctant to hold any hearings on this topic"), Paul testified on a bill he had introduced on July 30, 1980, "to repeal the privilege of banks to create money," the title, on enactment, to be the "Monetary Freedom Act." The bill outlined a plan for returning the United States to a full gold coin standard within two years of its passage. The bill provided for the 
repeal of legal tender laws; the redemption in gold coin or bullion in weights not less than five grams by the secretary of the Treasury 360 days after enactment of outstanding Federal Reserve notes at the mean of the spot prices of gold on the New York Commodity Exchange and the Chicago Board of Trade on five immediately preceding business days, redemption to cease after one year, and gold coin in circulation thereafter to function as the money of account, defined as the gram of gold, ninety-nine one-hundredths fine; cessation of the issue of Federal Reserve notes and United States notes on the date of enactment; free banking with a 100 percent reserve requirement effective 360 days after enactment. $^{5}$

The argument offered for repeal of legal tender laws is that the Constitution forbids the states to make anything but gold and silver a tender in payment of debt and does not permit the federal government to make anything a legal tender. Congress passed a legal tender act for the first time in 1862 to ensure acceptance of greenbacks. Repeal of the legal tender laws would free creditors to accept in payment for debts due them only what they have contracted to accept.

The other provisions of the bill need no elaboration. They are obviously constructed from libertarian principles and a belief in the superiority of commodity money.

Senator Helms delivered a statement to the Subcommittee on Mines and Mining but did not personally appear. He submitted a bill introduced in the Senate two days earlier by him and Senators Goldwater and McClure "to provide for the reinstatement of the dollar as a gold reserve currency, to stabilize the value of the dollar, and for other purposes." The bill translated into legislative language a plan that Arthur B. Laffer had published on February 29, 1980, as an economic study of A. B. Laffer Associates, "Reinstatement of the Dollar: The Blueprint."

Laffer's plan provides for an announcement by the United States of its intention to return to a convertible dollar at some prespecified time in the future, according to the bill, six months after enactment. The price of gold, designated the standard price of gold, would be fixed at the average price of gold bullion at New York for immediate delivery prevailing during the five business days preceding resumption of convertibility at the standard price. During the period before resumption, the Federal Reserve would maintain the monetary base literally unchanged and the Treasury and Federal Reserve would intervene neither in foreign exchange nor the government securities markets. Borrowings from Federal Reserve Banks would remain frozen.

On the day of resumption, the proportion of the total value of gold at the standard price of gold relative to the monetary base becomes the "target reserve quantity." Thereafter the Federal Reserve would 
stand ready to sell gold at $\mathbf{1 0 0 . 7}$ percent of the standard price of gold and to buy gold at 99.3 percent of the standard price, the minimum quantity having a value of $\$ 10,000$ at the standard price.

Should the gold reserve fall below 75 percent of the target reserve quantity, no change would be permitted in the monetary base. Should it fall below 50 percent of the target reserve quantity, the monetary base would be decreased by 1 percent per month. Should the gold reserve rise above 125 percent of the target reserve quantity, the monetary base would be increased by 1 percent per month. Should the gold reserve rise above 150 percent of the target reserve quantity, the monetary base would be increased by 2 percent per month. Should the gold reserve fall below 25 percent or rise above more than 175 percent of the target reserve quantity, the Board of Governors of the Federal Reserve would proclaim a gold holiday. During a gold holiday, the standard price would cease to apply, the Federal Reserve would neither buy nor sell gold from its reserves, and no change in the value of the monetary base greater than 1 percent would be permitted. A new standard price of gold would be determined by the average price of gold bullion during the five business days ending on the ninetieth day after the proclamation.

Congressman Paul described the provision for a gold holiday as "the weakest part" of Laffer's proposal "because it introduces the fact that you plan not to have a stable currency and credit supply. That means you expect and anticipate that we will continue with our Federal Reserve System, and with the Congress able to abuse the monetary system, and, therefore, you have to have a hedge, and this hedge is the gold holiday system. This may actually be worse than what we had before."'7

Laffer, who was a witness at the subcommittee hearings, defended the provision: "It is trying to protect from that situation that occurs infrequently but every 10,15 years when you have a brand new discovery of gold, if the quantity of gold triples, I would hate to say the price level rises. The objective again is still maintaining price stability of a bundle of goods and using gold as the controlling valve on the system, but not to, per se, control the dollar price of gold but to control the dollar price of gas [sic; goods?] and services and using as a regulator gold. When there is a disturbance in the gold market, I don't want to see the whole economy suffer inflation or deflation because of some change in that market."8

The contrast is evident between Helms's support of Laffer's variant of a traditional gold standard, with a fixed but adjustable price of gold, and with some modification of the existing institutional arrangements under the Federal Reserve System, and Paul's lack of interest in any form of a gold standard other than a 100 percent coin standard, with 
no face value for the coins, prices expressed in weights of gold, and a complete break with the existing institutional banking system.

\subsection{What Purpose Was the Commission Designed to Serve?}

We now turn to the question of what allies with such different gold objectives in mind hoped to achieve through the establishment of the Gold Commission.

Sponsors of a commission may have a variety of objectives. One objective may be to focus public attention on a problem that they regard as important. The sponsors may have a solution for the problem but lack the support for its implementation. One indication that the sponsors of the Commission set great store by this objective was their insistence that meetings of the Commission be open to the public. They objected strongly to the first closed meeting; thereafter, all meetings were open. Another objective may be to educate the public. Commissions can perform a genuine public service by collecting and summarizing facts and opinions on a national problem. They may make old ideas respectable, publicizing them and giving them legitimacy. Ideas that may have been limited to special groups may be given wider currency by a commission's study. Commissions may also serve to develop a consensus. The sponsors of the Gold Commission may well have had all these objectives in mind. ${ }^{9}$

The inclusion as members of representatives of constituencies with direct involvement in the problem under consideration-in this case, the Federal Reserve System-suggests that one purpose was to build a consensus or to develop support for a change in policy. A commission with bipartisan and bicameral balancing-as the law intended-is evidently designed to have political impact. Whatever the Commission recommended would be expected to meet the test of political acceptability.

The 1980 Republican Party platform included a paragraph on monetary reform that could be interpreted as a veiled reference to a projected return to a gold standard. The sponsors of the establishment of the Gold Commission possibly were counting on the White House to signal its interest in a strong pro-gold recommendation by the Commission. Such a signal would have influenced the designation of members. In that event, the number of members subject to White House influence would have formed a majority: four Republican Congressional members, the four public members, two members from the Council of Economic Advisers, and the chairman. No signal, however, apparently came from the White House.

As a result, the Commission came into existence with no sense of direction. The minority status of the pro-gold members of the Com- 
mission was not fully evident from the start. Whatever principled reasons the three Federal Reserve governors on the Commission (Partee, Rice, and Wallich) may have had to oppose an enlarged role for gold in the monetary system, they also had a strong self-interest in doing so, because of the implied rebuke to their conduct of monetary policy that such a recommendation would have conveyed. Their primary concern was to limit discussion touching on the performance of the Federal Reserve. Governor Wallich argued at the first meeting that the subjects of inflation and monetary policy were not a proper concern of the Commission. He was supported by the JEC House members (Reuss and Wylie), who repeatedly stressed that neither subject had been discussed in the House when the amendment to the IMF bill was introduced.

Both inflation and monetary policy, however, deeply concerned Jerry Jordan (a Council member) and Stephen Neal (the House Banking Committee majority member). The views of other congressional members (Senators Dodd and Schmitt, Senate Banking Committee minority and majority members, and Jepsen) were not initially well defined. Two Administration representatives-Murray Weidenbaum, chairman of the Council, and Secretary of the Treasury Regan-did not tip their hands until the final two meetings of the Commission. Of the four public members, one was a gold dealer (Herbert Coyne), one a businessman identified with conservative intellectual positions (Lewis Lehrman), one a California lawyer who had served in the Reagan state administration (Arthur Costamagna), one an economist, a former chairman of the Council of Economic Advisers, and a member of President Reagan's economic policy advisory board (Paul McCracken).

By the time the Commission had concluded its sessions, it was clear that the pro-gold group consisted of an awkward coalition of Congressman Paul and two of the public members, Lehrman and Costamagna. It was awkward because neither of the latter supported the conception of the monetary system that Paul advocated. Lehrman had in mind a traditional gold standard, restoring dollar convertibility into gold, although he also proposed changing Federal Reserve institutional arrangements, prohibiting open market operations and making the discount rate a penalty rate. ${ }^{10}$ As for Costamagna, his sole concern for the present was to provide the market with U.S.-minted bullion coins.

The maximum expectations of the sponsors would have been realized if there had been White House support for a strong pro-gold recommendation by the Commission. Failing that support, the sponsors were probably content to use the Commission as a forum to promote whatever use of gold they could prevail on the Commission to accept while focusing public attention on the importance they attached to a role for gold in the monetary system. 


\subsection{What Did the Sponsors Gain?}

\subsubsection{Commission Recommendations}

The Report of the Commission is in two volumes. Volume 1 contains what was conceived to be a report reflecting all views expressed by the members. An introductory chapter presents the Commission's recommendations on six subjects. Footnotes of dissent and qualifications of the recommendations by various members appear on nineteen of the twenty-one pages of the chapter. Four chapters follow. The first deals with the background of the establishment of the Commission; the second analyzes U.S. experience with gold since 1834; the third discusses types of monetary standards, including gold, other commodity, and paper money standards. The final chapter describes existing gold arrangements in the United States and proposals for change. An appendix on the gold market and a statistical compendium of time series relating to gold output, stocks, supply of and demand for gold, and the nominal and real price of gold complete the volume. Dissents by the Federal Reserve members, Congressmen Reuss and Wylie, and $\mathrm{Mr}$. Coyne appear on various pages of these chapters.

Volume 2 of the Report is described as "annexes." The bulk of the volume is occupied by a minority report.

The existence of a minority report was not revealed to the Gold Commission until a few days before the final revision of the Report that was intended to represent all views. The minority report was prepared under the direction of Congressman Paul and mirrors his views rather than those of Lewis Lehrman who endorsed it. Arthur Costamagna gave the minority report a qualified endorsement. He proposed delay in the implementation of the program outlined therein until the Reagan Administration's fiscal and monetary programs and the recommendations of the Gold Commission were given an opportunity to prove themselves. I discuss the minority report after examining the extent to which the Commission's recommendations accomplished ends that the pro-gold minority sought.

The majority rejected the proposal that the United States should fix the price of gold and restore gold reserve requirements for the Federal Reserve. Except for Lehrman, no member of the Commission advocated such a course. They rejected a return to fixed exchange rates and endorsed a floating exchange rate system. Again, only Lehrman held a brief for fixed exchange rates.

The main substantive proposal was the recommendation that the Treasury issue gold bullion coins of specified weights, without dollar denomination or legal tender status, to be manufactured from its existing stock of gold and to be sold at a small mark-up over the market 
value of the gold content, the coins to be exempt from capital gains taxes and from sales taxes. This recommendation was clearly a victory for both Helms and Paul. Senator Helms had cosponsored an October 5, 1981, bill (S. 1704) that provides for the minting of gold coins exempt from U.S. and state capital gains taxes. Assigning no legal tender status to the coins was a victory for Congressman Paul.

For the pro-gold forces, introducing gold coins into circulation was a first step toward achieving their ultimate objective of linking the monetary system to gold. For them, the step represents provision of a form of currency alternative to paper dollars. They conceive that holders will engage in transactions denominated in weights of coins rather than dollars. The other members who supported the recommendation did not share that conception. They regarded such coins as alternatives to foreign bullion coins that have found a market in the United States. For them, purchase of the coins would reflect an investment, not a transactions, demand.

At least six dissents were recorded with respect to exempting the coins from capital gains taxes for the obvious reason that the exemption would provide an incentive to shift from gold bullion holdings, common stocks, or productive assets to coins.

The members would not accept, as part of the recommendation, a price or quantity limit on the minting of the coins, leaving open the possibility that the demand might exhaust the Treasury's gold stock. Those who conceived of the demand for the coins as a transactions demand were opposed to a limit on the minting of the coins. A largescale demand for coins would, according to them, indicate dissatisfaction with the management of the dollar money supply and lead to the de facto establishment of a gold coin standard. On this view, establishment of an arbitrary quantity limit or a high seignorage fee would interfere with the expression of public preferences. Those who believed that the demand for coins would be an investment demand assumed that it would not be quantitatively significant, and on this ground neither opposed nor supported a legislated limit. Underlying this view is the assumption that only U.S. residents would acquire the coins in small quantities. It is conceivable, however, that domestic or foreign buyers would order large quantities on a given day. Such an order, if placed in the gold market, would raise the price. That consequence would not follow at the Treasury sales window.

Another aspect of the recommendation that official gold bullion coins be minted is the exclusion of private mints from the operation. Only the Treasury is accorded the right to mint such coins. Congressman Paul did not object to the restriction of the coinage to Treasury issues in the Report, volume 1 . He did so in the minority report. 
One other substantive recommendation of the Commission was that "the Congress and the Federal Reserve study the merits of establishing a rule specifying that the growth of the nation's money supply be maintained at a steady rate which insures long-run price stability." In a redundant sentence that is part of the same recommendation, the Commission added that "the Congress and the Federal Reserve should study ways to improve the conduct of monetary policy, including such alternatives as adopting a monetary rule." The recommendation was vehemently opposed by the three Federal Reserve Board governors and Congressmen Reuss and Wylie. The gold supporters voted for it. ${ }^{11}$ Congressman Neal offered a stronger resolution that the Commission recommend that "the Congress by legislation establish a rule specifying that the growth of the nation's money supply be maintained at a steady rate which insures long-run price stability." The members were evenly split on the vote for the resolution. Congressman Neal went on record with the statement that "by recommending more study rather than outright enactment of a monetary rule, we missed a golden opportunity to help secure long-term price stability, low interest rates, and high employment. I intend to continue my efforts to enact a monetary rule through legislation."

\subsubsection{Commission Hearings}

Two meetings of the Commission were devoted to hearings on the role of gold in domestic and international monetary systems. Twentythree witnesses testified. In addition, forty-seven individuals submitted written statements of their views.

The hearings validated Senator Helms's expectation that "there is little unanimity among the experts." The hearings provided an opportunity for views of Keynesians, monetarists, and neoclassical economists, as defined by Helms and Paul, to be heard. Of the twenty-three witnesses, only two for thrightly supported a return to a traditional gold standard. Two advocated nontraditional forms of a gold standard; one urged that gold be part of the solution to current problems, but prescribed no specific model. Two attorneys attacked the present monetary system as unconstitutional. The remaining witnesses were about evenly divided in ruling out any role for gold at the present or any time or in suggesting ways, short of a gold standard, to provide uses for gold, either as coin, cover for Treasury bond issues, market sales of gold to finance federal budget deficits, or to settle international payments imbalances.

The choice of witnesses was based on the rule the Treasury adopted that at least two members had to suggest the same individual. Some gold supporters apparently were disappointed that more witnesses supporting a traditional gold standard were not heard from. ${ }^{12}$ 


\subsubsection{Minority Report}

The minority report includes seven chapters. The first chapter deals with the present monetary crisis, which it dates from the closing of the gold window on August 15, 1971. Persistent inflation, high interest rates, a weak economy, and high unemployment are attributed to that event. The chapter focuses on monetarism as not an answer to the problem. "The monetarists share our view that the Federal Reserve's discretionary policy of the last several decades has been the cause of our inflation. However, we are confident that the monetarist solution is unworkable." The reason is that monetarism cannot be followed, that governments and the people in charge will "always abuse the 'right' to create money if it is granted to them." Moreover, "monetarism is similar to a discretionary inflationary policy in that the government remains as the monopolist fully in charge. In contrast, with a fully convertible gold standard, the people are in charge and can call the government's bluff anytime they choose by turning in their paper certificates for gold."

Before laying out the minority plans for a sound monetary system, the report presents two lengthy chapters, generally at a high level of scholarship, on U.S. money and banking history in the nineteenth and twentieth centuries. The conclusion is that that experience "illustrates the overwhelmingly superior caes for the gold standard as against any form of paper standard." The solution is to adopt a "modern gold standard" in two steps: first to tie the dollar to gold at a fixed weight and, after the public becomes accustomed to this concept, the currency unit will become that fixed weight. In addition, the central government's monopoly of the minting business must be abolished. It is the intervention of government that created problems under the historical gold standard. Laissez-faire must be applied to banking. "The historical evidence shows that monetary freedom does not fail, intervention by the government does."

The report then presents two chapters dealing with the case for monetary freedom and the case for the gold standard. The case for the gold standard is based on historical, theoretical, economic, and moral grounds.

The penultimate chapter deals with "the transition to monetary freedom."' It outlines three possible ways of reaching monetary freedom. One is government action to create the new system, but the danger is that it will result in a pseudo- rather than a real gold standard. ${ }^{13} \mathrm{~A}$ second way, in the absence of government action, is bottom-up reform-presumably voluntary actions by the public to use gold in ordinary transactions. A third way is for government to clear the obstacles now impeding reform from the bottom up. The immediate need under 
this option is for Congress to repeal the legal tender laws and the authority of the Federal Reserve to conduct open market operations. Failure to act will lead to the collapse of the official money and the official economy.

Four specific reforms are then outlined to roll back government and once again confine it within the limits of the Constitution. The monetary reforms include some already noted earlier: abolishing legal tender laws, defining the dollar as a weight of gold (the weight is not specified in the report), issuing gold coins to serve as an alternative monetary system to the present "paper money monopoly," permitting private mints to issue their own coins under their own trademarks, unrestricted money issues by competing issuers, retiring Federal Reserve notes and replacing them by notes redeemable in gold, silver, or some other commodity, 100 percent reserves to replace fractional reserve banking. Other reforms affect fiscal policy and are directed at a balanced budget, a reduction in both spending and taxes ("honest money and limited government are equally necessary in order to end our present economic crisis'), and the confining of government payments to gold or gold denominated accounts. Eventually also the government would accept gold as payment for all taxes, duties, and dues. Deregulation of banking and free entry would complete the reform program.

The chapter on transition concludes with one marked difference from the views Congressman Paul expressed in the hearings before the Subcommittee on Mines and Mining. There he stated, "If we proceed to a gold standard in an orderly fashion, such as I have proposed, then there will be no depression." 14 In the minority report, by contrast, we read: "The transition from the present monetary system to a sound system will probably not be painless, as some have suggested. Whenever the increase in the supply of money slows, there are always recessions. . . . In any transition to a sound monetary system there will, of necessity, have to be readjustments made in various sectors of the economy. Such readjustments will temporarily hurt certain individuals and enterprises." Six sectors that will suffer transitional difficulties are examined: real estate, agriculture, heavy industry, small business, exports, banking.

The prediction in the final chapter is that the "gold standard recession" will be short and mild. It is estimated that the transition will be accomplished in three years, the resulting recession lasting about a year. Thereafter ten years of prosperity will follow, with inflation, the business cycle, and high interest rates things of the past.

\subsubsection{Conclusion}

The creation of the Gold Commission served one paramount objective of its sponsors. It promoted discussion of gold in the media, on 
television, and among a lay public committed to the view expressed in the minority report that only gold is "honest" money. The minority report itself is a rallying call for the faithful. Both Helms and Paul were committed to the immediate objective of the minting of gold bullion coins by the Treasury. As the minority report noted: "We are extremely pleased that the Gold Commission has recommended to the Congress a new gold coinage. It has been almost fifty years since the last United States gold coins were struck, and renewing this Constitutional function would indeed be a cause for celebration and jubilee." 15 Short of the appointment of a Commission committed to restoring the gold standard, the sponsors probably view the limited results attained as a gain in achieving their ultimate objectives. ${ }^{16}$

The ultimate objectives of Helms and Paul differ but they may not part company in the interim. Like Lehrman, who did not want to distance himself from Paul and therefore endorsed the minority report, Helms may choose to support the more radical, populist posture that Paul supports than the more conventional one that he on his own might choose. ${ }^{17}$ The desire not to split the pro-gold forces was recently also made evident by Paul. He circulated a petition entitled "Economists for Gold" among economics departments of various universities. The gold standard described in the petition did not make clear that the gold standard Paul sought was not the traditional one.

On two issues, Paul found no support in the Gold Commission. He regards the present ten-year audit of the gold inventory as totally inadequate and proposed annual audits. As had Helms independently, he also sought restitution of IMF gold to member countries.

\subsection{Likely Impact of the Commission Report}

The commission reported on March 31, 1982. It is likely that in the months ahead reviews of the Report will appear in the economic journals and that its contents will be examined by public discussion panels. It will be judged on its adequacy in answering the questions directed to the Commission by the law that established it. Whatever the verdict will be on the quality of the Report, the pro-gold group will probably find satisfaction in the very fact that it provides an establishment discussion of gold. As an April 14 editorial of the Wall Street Journal expressed this view, "The Gold Commission ... has performed the very valuable service of reclaiming gold from the gold bugs." 18

But the pro-gold group was not the only group that derived satisfaction from the outcome. So also did many economists and commentators who do not favor an expanded role for gold, among whom I include myself. Some had initially feared a Commission dominated by "gold bugs" and were pleased to find that in the Commission as in the 
economics profession and in the informed public, the supporters of an enlarged role for gold were in a small minority.

It also remains to be seen whether the Congress will act on the recommendations of the Commission. Even before the Report was submitted to the Congress, the House Banking Committee issued a statement (signed by thirty members of the Committee, not including Congressman Neal) opposing the Commission's recommendation, adopted at its meeting on February 12, that the Treasury issue gold bullion coins. According to the statement, issue of coins, without legal tender status, would create monetary confusion; the capital gains tax exemption would damage the already weakened security markets; and the sales tax exemption would deprive the states of revenues needed to cover their enhanced obligations. The statement also objected to recommendations referring "to such matters as monetary growth rules and the system of floating as compared with fixed exchange rates. The Commission was not authorized to discuss these matters, was not constituted with a view to providing a balanced and professional perspective on them, did not discuss them adequately at its meetings, and should not have mentioned them in its Report." 19 Congressman Reuss led the opposition to the contents of the Report referred to in the Banking Committee's statement. Since he is retiring from the Congress at the end of the present session, there is a possibility that the new Congress may respond more positively to the recommendations.

What is undeniable is that continued monetary instability and high and variable inflation and interest rates are the breeding ground for support for a restoration of a monetary role for gold. It may be one of the ironies of history that the Commission was established when the inflation rate was slowing and therefore undercutting some of the rationale and urgency for a return to a gold standard expressed by its adherents. The pro-gold forces, however, predict that the recent slowing of inflation is temporary and that the battle against it will be won only on their terms. ${ }^{20}$

\section{Notes}

1. The date for the report of the Commission, according to the law establishing it, was October 7, 1981. Due to the delay in appointment of the members, legislation was introduced in the Congress and enacted as P.L. 97-47 on September 30,1981, to change the report date to March 31, 1982. Report to the Congress of the Commission on the Role of Gold in the Domestic and International Monetary Systems, 2 vols. (Washington, D.C.: Government Printing Office, March 1982). Pro-gold members would have preferred to extend the life of the Commission until June 30 . Those opposed to a role for gold (in 
particular, Congressman Reuss, at the Commission's first meeting) would have retained the original deadline.

2. Hereafter, cited as Feasibility; 96th Cong., 2nd sess., Serial No. 96-40 (Washington, D.C.: Government Printing Office, 1980).

3. U.S., Congress, Senate, Congressional Record, June 16, 1980, pp. S 7071 72 .

4. U.S., Congress, House, Congressional Record, September 18, 1980, pp. H 9136-37.

5. Feasibility, pp. 73-89. Quotation from p. 73.

6. Ibid., pp. $51-72$.

7. Ibid., p. 47.

8. Ibid., p. 48.

9. On the functions of commissions, see Frank Popper, The President's Commissions (New York: Twentieth Century Fund, 1970); Charles J. Hanser, Guide to Decision: The Royal Commission (Totowa, N.J.: Bedminster Press, 1965).

10. See his Monetary Policy, the Federal Reserve System, and Gold, January 25, 1980, circulated by Barton M. Biggs of Morgan Stanley Investment Research, January 29, 1980.

11. In a news release dated March 31, 1982, Senator Helms commented: "The conclusion of the Gold Commission was predictable considering the preconceived notions of the majority of the members. It was obvious from the outset that the stand-pat paper money advocates dominated the Commission, and that there was little likelihood that they would address the disastrous record of the past decade-the ten years the U.S. has been off a gold standard."

"If the U.S. does not move to adopt a gold standard, one day, historians will note that the nation's leadership failed to face the reality that the inflation and high interest rates are a result of not having a monetary standard. The closest the Commission came was to propose a study of a supply rule for money growth. Well, the Federal Reserve has tried a monetarist supply rule for the past two years, and what happened? We've had higher interest rates and more erratic money supply growth than ever before in the past."

12. In the news release referred to in the preceding note, Senator Helms complains about the inadequacy of the number of witnesses advocating "that the U.S. move swiftly to a gold standard. In all of the past six months of meetings, not one Commission member advocated replacing our present monetary disaster with a gold standard that would make the dollar convertible into gold at a fixed rate."

13. Paul has been influenced by Milton Friedman's article on "Real and Pseudo Gold Standards,' Journal of Law and Economics, 4 (October, 1961), 66-79, reprinted in his Dollars and Deficits (Englewood Cliffs, N.J.: PrenticeHall, 1968), pp. 247-65. Friedman described the post-World War I standard as a pseudo gold standard because it was not automatic but discretionary.

14. Feasibility, p. 7.

15. Report to the Congress of the Commission on the Role of Gold in the Domestic and International Monetary Systems, vol. 2, p. 269. The change in Congressman Paul's view on the subject may have evolved from his exposure to monetarist views expressed by Commission members. At the final meeting, Paul observed: "I would like to also state that even though my views are certainly not the majority views of this Commission, I think I have come to respect the views of others, especially those who recognize, as I do, that limiting the supply of money is a very important issue. I think that I have learned to understand that viewpoint, even though they would not make the use of gold as I would. I think that I understand that view better. I appreciate 
the information that I have gained from the Commission. I think this has been an important thing for me and I hope some others have benefited by this." Transcript of Seventh Meeting of the Gold Commission, United States Department of the Treasury, March 8, 1982, pp. 71-72.

16. Report, vol. 2, p. 260.

17. Senator Helms concludes in his news release of March 31: "The Commission did accomplish one goal-it brought to the public some information about the possibility - and I stress the word, possibility-of a new gold standard. And the public responded. The overwhelming majority of mail received by the Commission members, and the majority of material submitted by the public to the Commission, favored a new gold standard.

"The Commission's work, viewed in that light, could be another step toward a new monetary standard, which the economy desperately needs. The American people want one. We shall see if political leadership will get around to providing one."

I have the impression from the mail that I received on the subject of gold that the writers were not new converts. Much of it seemed to be inspired by a coordinating source with whom the writers were in touch.

18. In a letter to the Wall Street Journal, April 22, 1982, Senator Helms, commenting on the April 14 editorial in the paper, wrote: "I was saddened that members of the Commission focused their discussions almost entirely upon alleged inadequacies of past gold standards-with scarcely a mention of the gross inadequacy of the existing monetary fiasco."

19. Report, vol. 2, pp. 305-7.

20. In recent weeks the pro-gold group has been advocating a program of stabilization of the price of gold by Federal Reserve intervention. Open market purchases of government securities when the price of gold falls and sales when the price of gold rises have been recommended in articles by Jude Wanniski in the Wall Street Journal, by the April 14 editorial in the paper, and in a TV program by Arthur Laffer. The assumption underlying the recommendation is that any change in the price of gold is a response to monetary forces. The evidence of disturbances in demand and supply in the gold market unrelated to monetary forces is ignored by the proponents. 